\title{
Raji Cell Enzyme Immunoassay
}

National Cancer Institute

\section{Source}

National Cancer Institute. Raji Cell Enzyme Immunoassay. NCI Thesaurus. Code C135458.

A type of complement receptor-dependent immune complex assay that uses Raji cells washed with anti-IgA, anti-lg $\mathrm{G}$, anti-Ig $\mathrm{M}$, and anti-Ig $(\mathrm{A}+\mathrm{G}+\mathrm{M})$ conjug ated with an enzyme to detect the presence of circulating immune complexes in biologic fluids. 